Sādhanā, Vol. 9, Part 3, November 1986, pp. 239-254. (C) Printed in India.

\title{
A design for intrinsic control of anaerobic digestion
}

\author{
R ASHOK KUMAR
}

Engineering Department, O \& S Building, IV Floor, Trombay station 'B', Tata Electric Companies, Mahul Road, Chembur, Bombay 400074 , India

MS received 2 November 1983; revised 30 July 1986

\begin{abstract}
The article reports on a novel layout which achieves intrinsic control of anaerobic digestion of a wide range of feeds on a continuous basis. The feed is automatically controlled to match the digestion rate. The design consists of a shallow tank concentric with a gas holder resting on stoppers on the tank bottom. The height of the digesting fluid is maintained using the plug flow principle. The feed material is dropped into the annular space which is thereafter covered with a black plastic sheet to enable anoxic conditions to prevail. The bioliquid hydrolyses the material, with the help of prefermenting bacteria, into volatile acids. A steady migration of these volatile acids into the anaerobic digester is maintained by the concentration gradient, which is constantly replenished by the action of a syntrophic community of bacteria, producing methane. Further, the feasibility of the concept is reported on a system with a $45 \mathrm{~m}^{3}$ concrete tank and a $35 \mathrm{~m}^{3}$ steel gas holder by using a mix of domestic wastes and producing gas with $70 \%$ methane content reliably for hundred days continuously. A novel simulator is developed to predict the performance of the design at various parameters of operation. It is shown that the performance data for digesters analogous to the design reported here are interchangeable. Based on this, the average productivity of gas for various loadings is predicted within $\pm 10 \%$ of the actual yields for the analogous digesters. Because of the nature of the design, digestion of a wide range of feeds are permitted: without the problems faced in conventional layouts. This tremendous potential is realised by maintaining the integrity of the ecosystem of anaerobic digestion through the medium of the bioliquid which pervades the annular space as well as the confines of the anaerobic digester. By utilising the design in practice at normal loadings, its potential for reliable and economic digestion at a fraction of the cost of deep digesters could be realised if the predictions are confirmed at higher loadings by further work.
\end{abstract}

Keywords. Anaerobic digestion; plug flow principle; anoxic conditions; methane producing bacteria; concentration gradient. 


\section{Introduction}

Intrinsic control is characteristic of nature in which harmony exists among diverse living and non-living beings unless disturbed appreciably so that her benign margins vanish. The conventional design for an anaerobic digestion system to recycle "wastes" is to fragment the ecosystem represented by the digestion process into an isolated input handling system, an anaerobic digestion reactor or reactors and an effluent handling system. Material is then input into the anaerobic digester independent of the instantaneous reactions within the digester and corresponding material from the reactor is then output into the effluent handling system, in similar arbitrary fashion. Of course, broad design considerations would determine the rate of material input and output. In a single-stage digester such a method led to build up of acids within the digester when the infeed did not contain volatile acids and was usually associated with unreliable methane production. This eventually led to further fragmentation - this time of the anaerobic digester itself into two insulated compartments. The first was an anoxic stage for hydrolysing and liquefaction of the feed material and controlled storage of the feed material and breakdown products - fatty acids like acetic, butyric and propionic acids in it at low temperature $\left(20^{\circ} \mathrm{C}\right)$ which severely restricted methane production in this compartment. The second compartment is the anaerobic digester into which the volatile acids from the first were let in at some predetermined rate where a syntrophic community of acetogenic and methanogenic bacteria kept the acids from building up by sequentially or otherwise processing the acids to finally produce methane (see, for example, Asinari et al 1980). Still the two compartments were totally isolated from one another and the input and output from them determined by design considerations or average operating conditions at the most, by operating on the basis of gross parameters - volatile solids, $\mathrm{C} / \mathrm{N}$ ratio, methane production rate, $\mathrm{pH}$, alkalinity, temperature etc. This conventional way of externalising control had to face a number of problems, like how to normalise the state when something went wrong. This needs information on microlevel activities within the compartments and is not at present available. For example a typical layout of the two-stage continuously mixed digestion process (Asinari et al 1980) faced the problem of "garbage in-garbage out" when an increased concentration of volatile solids found its way straight into the effluent without being even partially converted. It acted merely as a catalyst to enable a greater amount of the volatile solids already present in the digester to be converted to methane during the same detention period as before. The amount of conversion to all products of the volatile solids was also unchanged. This suggests feedback of effluent which in this form of layout has again to be externally controlled, to avoid wastage of resources.

Continuously mixed digesters require energy for mixing. Further, in deep digesters $50 \%$ of the volatile solids would remain unused resulting in low gas productivity (Metcalf and Eddy 1979, p. 610). Well-known plug flow designs require no stirring, their gas productivity is high and gas produced is at least six times cheaper than conventional deep digesters (cf. Fry 1974; Subramanian et al 1979). However for a wide spectrum of feed material there is always the problem of processing of feed material, degradation of feed during storage, and floating material in digesters preventing gas production. The new design reported here is aimed at overcoming the above mentioned limitations and 
problems, while retaining the advantages of the plug flow digester. In this layout, the raw feed in an anoxic environment maintains intimate contact with the materials inside the digester through the medium of the bioliquid. This enables the volatile acids produced by breakdown of the raw feed by hydrolysis within the raw material container to migrate into the anaerobic digestion chamber continuously and synchronously with the rate of digestion. The result is an intrinsically controlled system in contrast to the conventional layouts which require costly external monitoring and control to optimise gas production and substrate utilisation, which even then cannot assure reliability.

Initial results obtained with this layout with gas production capacity of $35 \mathrm{~m}^{3}$ per day are also reported for a mix of domestic and garden wastes. A new model for simulating the performance of the design is described and applied to test its ability to predict the performance of analogous digesters. For this purpose published data on the performance of similar digesters has been utilised. These results are then used to predict the performance of the new design for various loadings and other parameters of operation.

\section{The annular layout for the anaerobic digestion system}

The anaerobic digestion system using the annular design is shown in figure 1 . It consists of a gas holder of $5.75 \mathrm{~m}$ diameter and $1.5 \mathrm{~m}$ average height floating in bioliquid in a concrete tank of $6.8 \mathrm{~m}$ diameter and $1.25 \mathrm{~m}$ height. The concrete tank would be ideally placed below ground level with only about $30 \mathrm{~cm}$ jutting out to prevent flooding and for safety. Initially in water the gas holder is heavy enough to sink to the bottom where stoppers (six in number) support the gas holder about $30 \mathrm{~cm}$ from the bottom of the concrete tank. A flexible rubber piping connects the gas holder via a manometer to a main gas valve. The valve is connected through a water trap to a piping system leading to a gas usage point some $30 \mathrm{~m}$ away. There is an annular space between the concrete tank and the steel gas holder and its volumetric capacity at $1.25 \mathrm{~m}$ height is about $13 \mathrm{~m}^{3}$. This annular space can hold about 12 to 13 tonnes of dry feed material. With $30 \%$ moisture remaining inside this dry matter the feed material would contain about $60 \%$ volatile solids for the domestic and plant wastes used here. This would amount to $20 \%$ overall concentration of volatile solids when the tank is filled with sewage or water up to $1 \mathrm{~m}$ height.

\subsection{The loading used for the preliminary run}

A rich mixture of hot fermenting grass, garden leaves, cuttings and fermenting kitchen garbage amounting to 3.25 tonnes was input into the concrete tank of figure 1. in the annular space between the concrete tank and the gas holder resting on stoppers on the bottom. The concrete tank was initially filled with $33.5 \mathrm{~m}^{3}$ of water. The wastes added made it up to $36 \mathrm{~m}^{3}$ capacity which is about $80 \%$ of the liquid holding capacity of the tank. While conducting the run the overflow pipe $0.3 \mathrm{~m}$ below the top is kept plugged. The surface of the biofluid in the concrete tank outside the gas holder is kept covered with a black plastic sheet to enable effective breakdown of organic matter plus prefermentation to take place. 

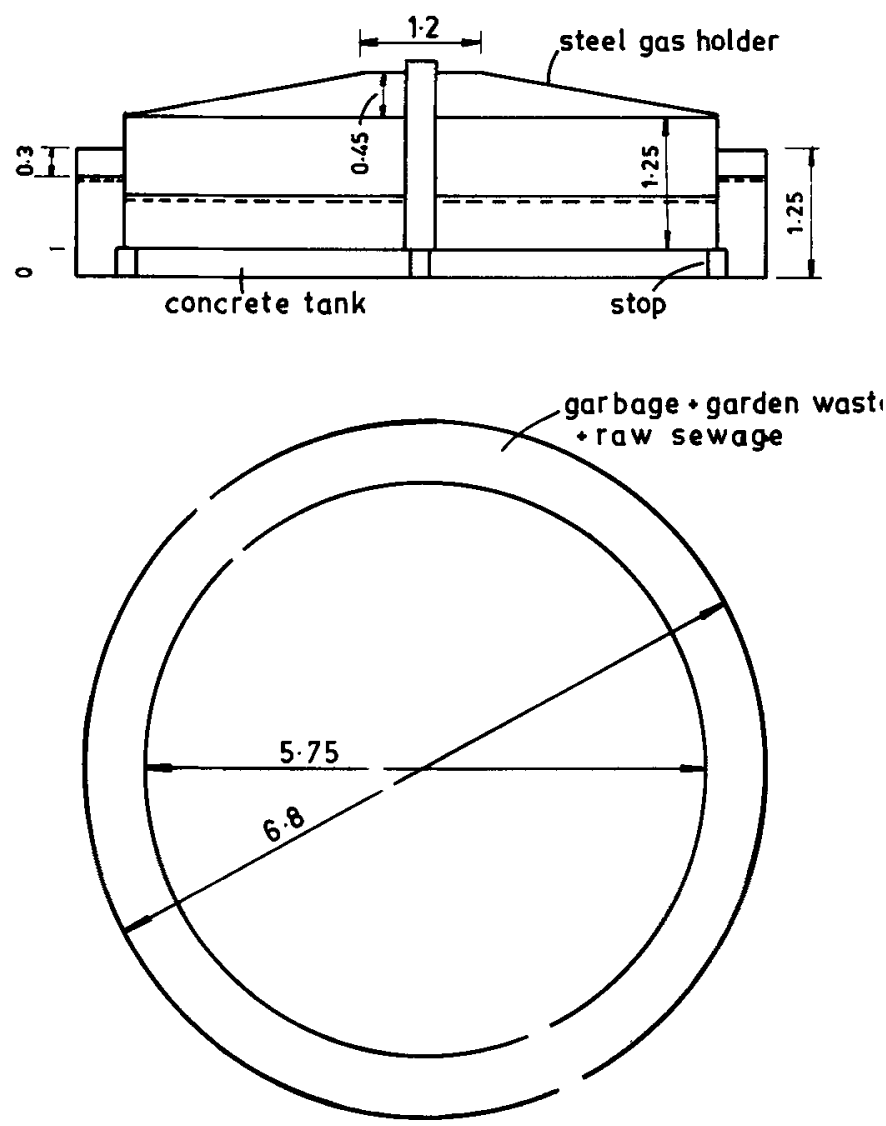

Figure 1. Design for intrinsic control of anaerobic digestion: the annular layout with plug flow reactor for second stage.

\subsection{The bottom of the gas holder}

The bottom of the gas holder has a number of cross members which prevent the aggregate material from rising inside the gas chamber and hence only the biofluid concentration is altered and accumulation of floating matter prevented.

\subsection{The space above the biofluid}

The dead space above the biofluid inside the gas chamber was filled with gas from a separate but leaky digester external to this system. This gas was composed of $0.5 \%$ oxygen, $2 \%$ carbondioxide, $0 \%$ to $5 \%$ methane and the rest nitrogen. The dead space measured $4.88 \mathrm{~m}^{3}$.

\subsection{Observations and measurements}

Observations were made of the gas pressure and of the height of the gas holder above a base level every hour from $0830 \mathrm{hrs}$ till $1830 \mathrm{hrs}$. At intervals the $\mathrm{pH}$ of the bioliquid as well as its alkalinity were measured. Orsat measurements were taken at intervals to record improvements in oxygen and carbondioxide composition. 
Occasional measurements of gas chromatography were conducted to determine methane level. Gas was burnt in a gas burner regularly to determine the earliest time of gas burning. The temperature of the bioliquid (spot measurements) was also determined.

2.4a No special seeding measures were necessary: The run demonstrated that no special seeding with contents of an actively digesting unit is necessary other than that contained in the input material as described above.

2.4b Changes upon addition of the charge: The changes that took place upon addition of the charge are presented in table 1 . These observations and measurements show that within seventeen days, from 4 to 21 September, usable gas was being produced without any seeding measures being adopted. The rise in $\mathrm{pH}$ and alkalinity show that the reactions are proceeding normally. Further since the methane content has remained constant at $70 \%$ as shown by the gas chromatographic measurements for 4 October as well as for 31 October, the process has stabilised and indicates reliability.

\subsection{How intrinsic control works in the annular layout}

The domestic wastes packed into the annular space between the concrete tank and the gas holder are hydrolysed by the action of liquefying fermentative bacteria which convert the complex organics into simpler molecules. These are usually volatile fatty acids like acetic, propionic and butyric acids. The raw materials in the annular space tend to accumulate the volatile fatty acids, thus severely retarding methane production in the annular space. On account of the concentration gradient between the material in the annular space and in the digester, the volatile acids migrate into the digester where they are acted upon by a syntrophic community of acetogenic and methanogenic bacteria to produce methane. Digestion continuously

Table 1. Changes upon addition of charge

\begin{tabular}{|c|c|}
\hline Date & Observation \\
\hline $4-9-82$ & of the system completed ( 3.25 tonnes). The gas holder was at $\mathrm{d}$ \\
\hline-82 & ressure in the gas holder $6.5 \mathrm{~cm}$ (water column \\
\hline $12-9-82$ & Maximum gas pressure $13 \mathrm{~cm}$. Tank still on stoppers. \\
\hline $13-9-82$ & $\begin{array}{l}\text { Tank lifts and maximum pressure observed } 14 \mathrm{~cm} \text {. Maximum tank lift } 5 \mathrm{~cm} ; \mathrm{pH} \text { of bioliquid } \\
6.0 \text {; ambient temperature } 30^{\circ} \mathrm{C} \text {; bioliquid temperature } 33^{\circ} \mathrm{C} \text {. }\end{array}$ \\
\hline $14-9-82$ & pH of bioliquid inside digester within gas holder $6 \cdot 0$; alkalinity $515 \mathrm{ppm}$. \\
\hline $16-9-82$ & $\begin{array}{l}\text { Orsat analysis conducted on gas inside gas holder: carbondioxide } 11 \% \text {, oxygen } 0 \% \text {. } \\
\text { Maximum tank lift } 10 \mathrm{~cm} \text {; maximum pressure } 15 \mathrm{~cm} \text {. }\end{array}$ \\
\hline $17-$ & Maximum tank lift $14 \mathrm{~cm}$; maximum pressure $15.5 \mathrm{~cm}$ \\
\hline $20-$ & $\begin{array}{l}\text { Maximum tank lift } 23 \mathrm{~cm} \text {; maximum pressure } 15.5 \mathrm{~cm} \text {; pH } 6.8 \text {; bicarbonate alkalinity } \\
700 \mathrm{ppm} \text {. }\end{array}$ \\
\hline 21-9-82 & $\begin{array}{l}\text { Gas burnt with a blue flame which brought one litre of water to boil in } 20 \text { minutes, on an } 8 \\
\text { cft }\left(0.2265 \mathrm{~m}^{3}\right) \text { per hour gas burner. }\end{array}$ \\
\hline-82 & $\mathrm{pH} 7.0$; alkalinity $630 \mathrm{ppm}$ of the bioliquid within the gas holder. \\
\hline & Orsat measurement showed carbondioxide $19 \%$ and oxygen $0 \%$. \\
\hline $4-10-82$ & $\begin{array}{l}\text { Methane content } 71 \% \text {; carbondioxide } 29 \% \text {. Maximum tank lift } 40 \mathrm{~cm} \text {; gas burnt with a blue } \\
\text { flame. }\end{array}$ \\
\hline & Methane content $71 \%$; carbondioxide $29 \%$. \\
\hline
\end{tabular}


replenishes the concentration gradient. The volatile acids do not accumulate within the digester because of the nature of the bacteria (Asinari et al 1980). The infeed of volatile acids is therefore maintained continuously in synchronism with the rate of digestion.

2.5a The ecosystem controls truly continuous operation: The loading rate of the digester is not in an open ended fashion as in conventional layouts. The responsibility for the correct amount of instantaneous input has been left to the ecosystem itself. Thus there is a feedback of conditions within the digester to the ecosystem in the annular space continuously and vice versa, instead of being dependent upon open loop external measurements, resulting in a harmonious operation of the digestion system - a truly continuously fed digester. This therefore has tremendous potential as it permits digestion of a wide range of feed material without mismatch of feed rate and other problems faced in the conventional layout. The design of the annular layout, by keeping the ecosystem of the digestion process intact and whole, allows the process to control itself automatically by maintaining interdependence via the medium of the bioliquid, in accordance with the needs of the members of the ecosystem.

2.5b Design of the anaerobic digester portion: While intrinsic control is the raison detre for the annular layout, high gas productivity is aimed at in the design of the anaerobic digester for the second stage of the process. It is designed as a plug flow digester. Thus it is very shallow - the ratio of the height of the biofluid to the radius of the gas holder varies from one-third to one-seventh in the ideal case. In our case this ratio is nearer one-third. Actually the cylindrical shape for the shallow digester can be construed as a coalescence of an infinite number of plug flow digesters into the cylundrical shape. Thus imagine a diametral plane normal to the tank bottom and vertical strips of biomaterial proceeding along this vertical plane towards the central axis along the concentration gradient. As the strips proceed towards the centre they are acted upon by the syntrophic bacterial consortium to produce methane in volcanic fashion (Fry 1974). In the ideal plug flow case, these strips form concentric cylindrical bodies proceeding towards the central axis. The productivity of such a plug flow digester by analogy with the conventional plug flow digester would be of the order of $1 \mathrm{~m}^{3}$ per day per $\mathrm{m}^{3}$ of liquid holding capacity of the digester, under appropriate bioliquid temperature and concentration conditions. Further, because of the volcanic action of gas evolution, no stirring is required.

2.5c The provision of anoxic conditions inside the annular space: Anoxic conditions were provided inside the annular space by covering the top of the biomaterial in the space with a black plastic sheet. The raw material in the annular space together with water in the tank then get partitioned in the annular gap into three zones like in a lagoon: a top aerobic layer, an intermediate aerobic-anaerobic zone and a bottom anaerobic zone. Even though some volatile solids get converted in this space, the productivity in the second stage - the plug flow reactor - more than makes up for this loss (see DST 1981 and Asinari et al 1980). To maximise productivity in the second stage, however, the degree of anoxic conditions to be provided may extend all the way up to making arrangements for tapping off the low 
BTU gas produced in the first stage. This paper confines itself to the simplest arrangement using a black plastic sheet covering and studying gas production in the second stage.

\section{Productivity of the annular layout}

The aim of the initial test run was to establish the feasibility of the concept. The initial concentration of volatile solids was $3 \cdot 14 \%$ in the annular space, and $0.9 \%$ overall in the tank. The corresponding production of gas over a detention period of 100 days was remarkably consistent - the average gas production being $0.035 \mathrm{~m}^{3}$ per day per $\mathrm{m}^{3}$ of liquid holding capacity of the digester, with a standard deviation of $0.00448 \mathrm{~m}^{3}$ per day per $\mathrm{m}^{3}$ of digestion liquor. The individual daily gas production figures were within 0.5 to $1.5 \sigma$ of the average. Figure 2 shows a sample of the daily gas production. The methane content was constant at $70-71 \%$ and the carbondioxide content was $29-30 \%$. The average bioliquid temperature was $33^{\circ} \mathrm{C}$ and the average ambient day time temperature $30^{\circ} \mathrm{C}$. The total gas production was $128 \mathrm{~m}^{3}$ at STP and the amount of volatile solids added was $325 \mathrm{~kg}$, giving a gas productivity of $0.4 \mathrm{~m}^{3} / \mathrm{kg}$ of volatile solids added. Gas production with $70 \%$ methane content was $114 \mathrm{~m}^{3}$ (STP) corresponding to the daily productivity figures given above. During the run some gas was cold flared and this has also been taken into consideration in computing the total amount of gas produced.

\subsection{Feasibility of intrinsic control of anaerobic digestion in the annular layout}

The above run demonstrated the feasibility of reliable digestion to produce methane by automatic intrinsic control of feed in the annular layout on a continuous basis for 100 days. What remains to be seen is whether the above results are indicative of its potential at higher concentrations of infeed and whether on the

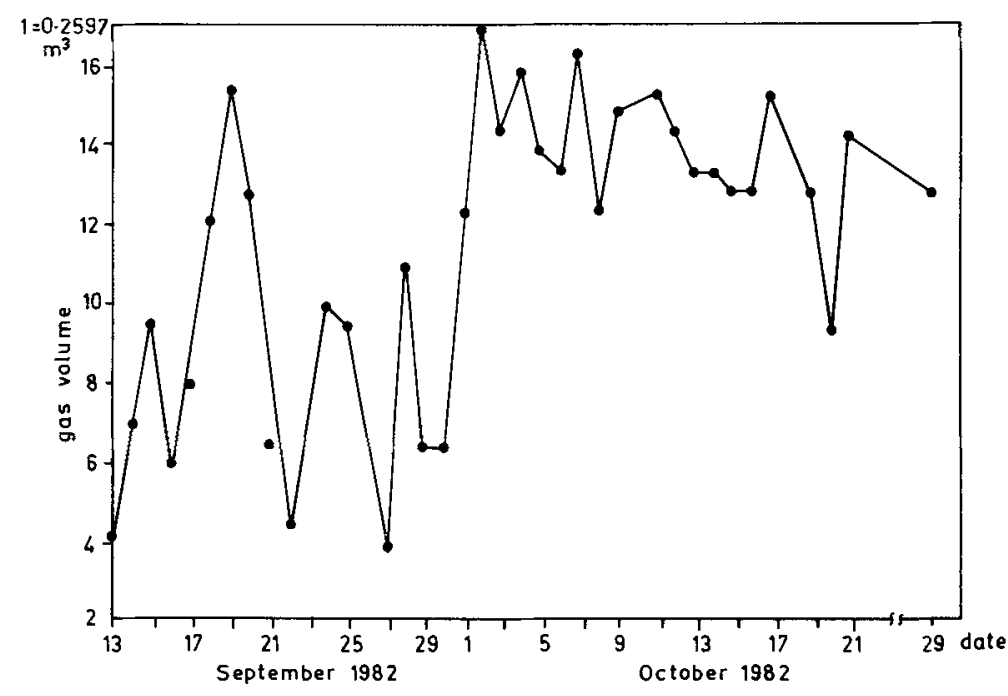

Figure 2. Intrinsically controlled anaerobic digestion. Daily gas production between $\mathbf{0 8 3 0}$ and 1330 to $1430 \mathrm{hrs}$. 
basis of these results we can predict its performance with a reasonable degree of confidence for various foreseeable conditions of operation in daily use. The next sections answer these questions with the help of a model to simulate the behaviour of the new design.

3.2 Correlation of performance of annular layout with published performance data for analogous anaerobic digesters

It is assumed that ariaerobic digesters analogous to plug flow digesters behave, on the average, according to the following model: Average gas productivity $S$ in $\mathrm{m}^{3} /$ day $/ \mathrm{m}^{3}$ of digesting liquid volume can be expressed by

$$
S=k . \quad C T / D M,
$$

where $C=$ volatile solids concentration in the digester as percentage of bioliquid volume of the digester; $T=$ absolute temperature gradient from $0^{\circ} \mathrm{C}$ to the temperature of the bioliquid $T^{\circ} \mathrm{C} ; D=$ detention time in days of the feed in the digester; $M=$ percentage methane content of gas; $k=$ constant of proportionality, same for analogous digesters. For example, as demonstrated below for digesters analogous to plug flow type, the value of this constant $\approx 8.25$ for the larger capacities and the average for all sizes would be $\approx 8.0$ with a standard deviation $s$ of about $0 \cdot 3$. To study this, let us consider the published performance parameters of some analogous digesters. From (1),

$$
k=S D M / C T \text {. }
$$

The performance parameters for the various digesters are given in table 2 . Inserting values for $S, D, M, C$ and $T$ for each digester in turn from this table, we obtain the values for $k$ for each digester which have been tabulated in table 3 .

From table 3 we identify two distinct groups of digesters, one having the characteristic constant $k=8.08$ - the plug flow group, and the other, the deep digester with $k=4 \cdot 38$ to 5 . For the plug flow digester group we observe that the $k$ values are within $10 \%$ of each other. For the larger digesters, namely, the annular lavout design of this paper $\left(35 \mathrm{~m}^{3} /\right.$ day gas production capacity), the Fry digester $\left(85 \mathrm{~m}^{3}\right)$ and the NSI Kanpur digester $\left(50 \mathrm{~m}^{3}\right)$, the values for $k$ are within $0.5 \%$ of each other. This is a very satisfying result considering that the digester data have been obtained from independent investigators from around the world - Britain, Belgium, USA, Kanpur and Bombay. Therefore, for our simulation, we consider that a single value for $k$ holds for the analogous digesters 1 to 5 in table 3 .

3.2a Simulation of the performance of the annular layout: For our annular layout digester (annular digester) using (1) the gas productivity $S_{0}$ at operating parameters $C_{0}, T_{0}, D_{0}$, and $M_{0}$ is given by

$$
S_{0}=k C_{0} T_{0} / D_{0} M_{0} \text {. }
$$

For any other set of parameters $C, D, T$, and $M$ the gas productivity is by (1),

$$
S=k C T / D M \text {. }
$$

Dividing (4) by (3) we obtain:

$$
S / S_{0}=C T D_{0} M_{0} / C_{0} T_{0} D M
$$


Table 2. Accuracy of prediction of performance of annular digester at various performance parameters

\begin{tabular}{|c|c|c|c|c|c|c|c|}
\hline \multirow[b]{3}{*}{ Parameter } & \multicolumn{7}{|c|}{ Digester type } \\
\hline & \multicolumn{4}{|c|}{ Plug flow digesters } & \multicolumn{3}{|c|}{ Deep digesters } \\
\hline & Annular & Hawkes & Asinari & Fry & NSI & KVIC & ASTRA \\
\hline $\begin{array}{l}\text { Concentration (\%) } \\
\text { Temperature of }\end{array}$ & $0 \cdot 9$ & $2 \cdot 03$ & $5 \cdot 93$ & 20 & $11 \cdot 5$ & 7.08 & 7.08 \\
\hline $\begin{array}{l}\text { bioliquid }\left({ }^{\circ} \mathrm{C}\right) \\
\text { Detention (days) } \\
\text { Methane (\%) }\end{array}$ & $\begin{array}{c}33 \\
100 \\
70\end{array}$ & $\begin{array}{l}20 \cdot 3 \\
34 \cdot 4 \\
85.2\end{array}$ & $\begin{array}{l}35 \\
14 \\
60\end{array}$ & $\begin{array}{c}35 \\
61 \cdot 93 \\
70\end{array}$ & $\begin{array}{c}35 \\
45 \\
55-60\end{array}$ & $\begin{array}{l}27 \cdot 6 \\
50 \cdot 00 \\
60-70\end{array}$ & $\begin{array}{l}27 \cdot 6 \\
42 \cdot 83 \\
60-70\end{array}$ \\
\hline $\begin{array}{l}\text { Actual average gas } \\
\text { productivity (STP) }\end{array}$ & 0.035 & $0 \cdot 106$ & $2 \cdot 0$ & $1 \cdot 33$ & $1 \cdot 235$ & 0.285 & $0 \cdot 381$ \\
\hline $\begin{array}{l}\text { Prediction of gas pro- } \\
\text { ductivity of reactor } \\
\text { Digester liquid holding }\end{array}$ & $0.034^{*}$ & $0 \cdot 116$ & $2 \cdot 038$ & $1 \cdot 332$ & $1 \cdot 23$ & $(0.496)$ & $(0.579)$ \\
\hline $\begin{array}{l}\text { capacity }\left(\mathrm{m}^{3}\right) \\
\text { Material use } \mathrm{m}^{3} \text { gas } / \mathrm{kg}\end{array}$ & 32.46 & Lab & scale & 85 & 50 & $15 \cdot 02$ & $12 \cdot 85$ \\
\hline $\begin{array}{l}\text { volatiles } \\
\text { Percent deviation }\end{array}$ & $0 \cdot 400$ & $0 \cdot 577$ & $0 \cdot 550$ & $0 \cdot 410$ & 0.574 & $0 \cdot 200$ & $0 \cdot 231$ \\
\hline$[(5-6) / 5] 100$ & $2 \cdot 86$ & $-9 \cdot 4$ & -1.91 & -0.15 & 0.4 & -74 & -52 \\
\hline Source & This paper & $\begin{array}{c}\text { Hawkes } \\
\text { et al } \\
(1980)\end{array}$ & $\begin{array}{l}\text { Asinari } \\
\text { et al } \\
(1980)\end{array}$ & $\begin{array}{c}\text { Fry } \\
(1974)\end{array}$ & $\begin{array}{c}\text { DST } \\
(1981)\end{array}$ & $\begin{array}{l}\text { Subraman } \\
(1979)\end{array}$ & an et al \\
\hline
\end{tabular}

* For the annular design the prediction is the average obtained from table 6.

In (5) knowing all parameters except $S$, we can compute $S$, the gas productivity at the new parameters $C, T, D, M$, for the annular digester.

In table 2 we have the published parameters of a number of digesters analogous to our annular digester: plug flow (Fry 1974; Hawkes et al 1980), two-stage continuously mixed digestion (Asinari et al 1980) (the two stages together operate approximately as a plug flow digester, c.f. Metcalf \& Eddy 1979), and the batch reactor of the National Sugar Institute (NSI) of Kanpur along with our annular digester. What would the annular layout achieve for its gas productivity at the performance parameters of these digesters? When we insert in (5) the performance parameters $C, T, D$, and $M$ for Fry's digester and $C_{0}, T_{0}, D_{0}, M_{0}$ and $S_{0}$ for the annular digester, we obtain for our digester a gas productivity value of 1.332 which is within $0.15 \%$ of the gas productivity Fry's digester actually achieved.

Table 3. Values of digester characteristic constant $k$

\begin{tabular}{lllc}
\hline Digester & Type & Reference & Value of $k$ \\
\hline Annular & Plug flow & This paper & $8 \cdot 25$ \\
Fry & Plug flow & Fry (1974) & $8 \cdot 24$ \\
Hawkes & Plug flow & Hawkes et al (1980) & 7.54 \\
Asinari & Two-stage & Asinari et al $(1980)$ & $8 \cdot 09$ \\
NSI & Batch & DST (1981) & $8 \cdot 28$ \\
KVIC & Deep & Subramanian et al (1979) & $4 \cdot 38$ \\
ASTRA & Deep & Subramanian et al (1979) & $5 \cdot 01$ \\
Average of digesters 1 to 5 & & 8.08 \\
Standard deviation of digesters 1 to 5 & & 0.31 \\
Standard deviation as \% of average & & $3 \cdot 85 \%$ \\
\hline
\end{tabular}


With $C 20 \%, T 35^{\circ} \mathrm{C}, D 61.93$ days and $M 70 \%$ for Fry's digester, and $C_{0} 0.9 \%, T_{0}$ $33^{\circ} \mathrm{C}, D_{0} 100$ days, $M 70 \%$ and $S_{01} 0.035$ for the annular digester from table 2, we obtain for $S$ from (5):

$$
\begin{aligned}
S & =(20 / 0.9)(35 / 33)(100 / 61.93)(70 / 70)(0.035) \\
& =38.06 \times 0.035 \\
& =1.332 \mathrm{~m}^{3} / \text { day } / \mathrm{m}^{3} .
\end{aligned}
$$

Let us now perform a similar exercise; this time let us see how Fry's digester would perform for the parameters of the batch digester of the National Sugar Institute of Kanpur:

From table 2 now, with $C_{0} 20 \%, T_{0} 35^{\circ} \mathrm{C}, D_{0} 61.93$ days, $M_{0} 70 \%$ and $S_{0} 1.33$, for Fry and $C 11.5 \%, T 35^{\circ} \mathrm{C}, D 45$ days, and $M 60 \%$, for NSI, Kanpur,

$$
\begin{aligned}
S & =(11 \cdot 5 / 20) .(35 / 35)(61.93 / 45)(70 / 60)(1.33) \\
& =(0.9232)(1 \cdot 33) \\
& =1,228 .
\end{aligned}
$$

Thus Fry's digester would attain a gas productivity of 1.228 at the parameters of the Kanpur batch digester. The batch digester productivity was $1 \cdot 235$. The deviation in the predicted gas yield of the Fry's digester from that yielded by the Kanpur batch process digester is $0.58 \%$. What would the Kanpur batch digester yield for the parameters of Fry's digester? The answer is immediately obtained by inserting in the reciprocal of (5) the above values for the Fry and Kanpur parameters:

From (7) above,

$$
\begin{aligned}
S \text { (Kanpur) at Fry } & =(1 / .9232)[S \text { (Kanpur) }] \\
& =(1.08319)(1.235) \\
& =1.338 .
\end{aligned}
$$

The deviation in the predicted gas yield of the Kanpur batch digester for the parameters of the plug flow digester of Fry is $-0.58 \%$, from the gas productivity actually achieved by . Fry's digester.

Thus the predicted productivity of digester $a$ with respect to actual reported value of digester $b$ at the performance parameters of digester $b$ is determined by inserting values of the performance parameters of the respective digesters into the simulator

$$
S_{a}^{b} / S_{b}=\left(C_{b} / C_{a}\right)\left(T_{b} / T_{a}\right)\left(D_{a} / D_{b}\right)\left(M_{a} / M_{b}\right)\left(S_{a} / S_{b}\right),
$$

where $S$ is the gas productivity (average), $\mathrm{M}^{3} \mathrm{D}^{-1} \mathrm{M}^{-3}$ of digesting liquid, $D$ is the detention time in days, $M$ is the methane content of the gas in percent, $C$ is the volatile solid concentration as percentage of the liquid holding volume of the digester, and $T$ is the temperature of the bioliquid in ${ }^{\circ} \mathrm{C}$. The subscripts and superscripts have the following meaning: $S_{a}$ means actual reported average productivity of digester $a$, etc. $S_{a}^{b}$ means predicted average productivity of digester $a$ with respect to actual reported average productivity of digester $b$ at the performance parameters of digester $b$ etc. 
Table 4. Predictions of average gas productivity

\begin{tabular}{lccccc}
\hline & \multicolumn{4}{c}{ with respect to } \\
\cline { 2 - 6 } Productivity of & Annular & Fry & Hawkes & Asinari & NSI, Kanpur \\
\hline Annular & 0.035 & 0.035 & 0.032 & 0.034 & 0.035 \\
Fry & & 1.33 & 1.217 & 1.307 & 1.338 \\
Hawkes & & 0.106 & 0.114 & 0.116 \\
Asinari & & & & 2.00 & 2.047 \\
NSI, Kanpur & & & & & 1.235 \\
\hline
\end{tabular}

From (8) it follows that

$$
S_{a}^{b} / S_{b}=S_{a} / S_{b}^{a} .
$$

Thus for the five analogous digesters considered here there are ten independent values for the relative gas productivities as shown by (9). On account of the nature of the simulator model (8), we can further predict not only gas productivities but also the other operating parameters - concentration, detention, temperature and methane concentration in similar fashion. The relevant relations are similarly derived as done above and they are

$$
\frac{S_{a}^{b}}{S_{a}}=\frac{D_{a}^{b}}{D_{a}}=\frac{M_{a}^{b}}{M_{a}}=\frac{C_{b}^{a}}{C_{h}}=\frac{T_{b}^{a}}{T_{b}}=\frac{S_{b}}{S_{b}^{a}}=\frac{D_{b}}{D_{b}^{a}}=\frac{M_{b}}{M_{b}^{a}}=\frac{C_{a}}{C_{a}^{b}}=\frac{T_{a}}{T_{a}^{b}} .
$$

The ten independent predictions for the average gas productivities are tabulated in the matrix in table 4 . The deviations of the predicted gas yields from the actual average yields reported by the various authors cited are brought out in table 5 . The measured range of deviations in predicted gas yield is $8 \cdot 61 \%$ to $-9.89 \%$. If these deviations are merely due to random errors they should normally cancel out yielding for the average deviation a much lesser value, which is the case for an average of $0.021 \%$ (275 times less than standard deviation).

With the help of (10) all the predictions have been computed and tabulated, in table 6 are the absolute values, and in table 7, the deviations. It is seen that the deviations of the predictions from the actual reported values are within $\pm 10 \%$. It may be noted that the predictions are not only for the gas yield but also for other parameters: concentration, temperature, detention period and methane content.

\begin{tabular}{|c|c|c|c|c|c|}
\hline \multirow[b]{2}{*}{ Deviation of } & \multicolumn{5}{|c|}{ with respect to } \\
\hline & Annular & Fry & Hawkes & Asinari & NSI, Kanpur \\
\hline $\begin{array}{l}\text { Annular } \\
\text { Fry } \\
\text { Hawkes } \\
\text { Asinari } \\
\text { NSI, Kanpur }\end{array}$ & & $0 \cdot \overline{15}$ & $\begin{array}{l}8 \cdot 61 \\
8 \cdot 47\end{array}$ & $\begin{array}{r}1 \cdot 87 \\
1 \cdot 73 \\
-7 \cdot 37\end{array}$ & $\begin{array}{l}-0.43 \\
-0.58 \\
-9.89 \\
-2.35\end{array}$ \\
\hline
\end{tabular}

Table 5. Deviations of gas productivity from actual values as percentages of actual values

Average of the ten values of deviations: $0.021 \%$ standard deviation $s: 5 \cdot 874 \%$ Note: Only independent values have been tabulated. 
Table 6. Predicting analogous digester behaviour

\begin{tabular}{|c|c|c|c|c|c|}
\hline & $\begin{array}{l}\text { Productivity } \\
\left(\mathrm{M}^{3} \mathrm{D}^{-1} \mathrm{M}^{-3}\right)\end{array}$ & $\begin{array}{c}\text { Concentration } \\
\text { volatile } \\
\text { solids }(\%)\end{array}$ & $\begin{array}{l}\text { Temperature } \\
\left({ }^{\circ} \mathrm{C}\right)\end{array}$ & $\begin{array}{l}\text { Detention } \\
\text { (days) }\end{array}$ & $\begin{array}{c}\text { Methane } \\
(\%)\end{array}$ \\
\hline \multicolumn{6}{|c|}{ Annular digester } \\
\hline Actual & 0.035 & 0.90 & $33 \cdot 00$ & $100 \cdot 00$ & $70 \cdot 00$ \\
\hline Fry & 0.035 & 0.90 & $33 \cdot 05$ & 99.85 & $69 \cdot 89$ \\
\hline Hawkes & 0.032 & 0.98 & $36 \cdot 11$ & 91.40 & 63.97 \\
\hline Asinari & 0.0 .34 & 0.92 & $33 \cdot 63$ & $98 \cdot 10$ & $68 \cdot 69$ \\
\hline NSI & 0.0135 & 0.90 & $32 \cdot 86$ & $100 \cdot 40$ & $70 \cdot 30$ \\
\hline \multicolumn{6}{|c|}{ Fry's digester } \\
\hline Actual & $1 \cdot 330$ & $20 \cdot 00$ & $35 \cdot 00$ & 61.93 & $70 \cdot 00$ \\
\hline Annular & $1 \cdot 332$ & $19 \cdot 97$ & 34.95 & $62 \cdot 66$ & $70 \cdot 83$ \\
\hline Hawkes & $1 \cdot 217$ & $21 \cdot 85$ & $38 \cdot 24$ & $56 \cdot 68$ & $64 \cdot 07$ \\
\hline Asinari & 1.307 & $20 \cdot 35$ & $35 \cdot 61$ & $60 \cdot 85$ & $68 \cdot 79$ \\
\hline NSI & $1 \cdot 338$ & $19 \cdot 88$ & $34 \cdot 80$ & $62 \cdot 29$ & $70 \cdot 41$ \\
\hline \multicolumn{6}{|c|}{ Hawkes et al } \\
\hline Actual & $0 \cdot 106$ & $2 \cdot 03$ & $20 \cdot 30$ & $34 \cdot 40$ & $85 \cdot 20$ \\
\hline Annular & $0 \cdot 116$ & $1 \cdot 86$ & $18 \cdot 55$ & $37 \cdot 64$ & 93.23 \\
\hline Fry & $0 \cdot 116$ & 1.86 & $18 \cdot 58$ & $37 \cdot 58$ & 93.08 \\
\hline Asinari & 0.114 & 1.89 & $18 \cdot 91$ & $36 \cdot 93$ & $91 \cdot 47$ \\
\hline NSI & $0 \cdot 116$ & 1.85 & $18 \cdot 47$ & $37 \cdot 80$ & 93.66 \\
\hline \multicolumn{6}{|c|}{ Asinari et al } \\
\hline Actual & $2 \cdot 00$ & $5 \cdot 93$ & $35 \cdot 00$ & $14 \cdot 00$ & $60 \cdot 00$ \\
\hline Annular & $2 \cdot 038$ & $5 \cdot 82$ & $34 \cdot 34$ & $14 \cdot 27$ & $61 \cdot 15$ \\
\hline Fry & 2.035 & $5 \cdot 83$ & $34 \cdot 40$ & $14 \cdot 25$ & $61 \cdot 05$ \\
\hline Hawkes & $1 \cdot 863$ & $6 \cdot 37$ & $37 \cdot 58$ & $13 \cdot 04$ & $55 \cdot 89$ \\
\hline NSI & $2 \cdot 047$ & $5 \cdot 79$ & $34 \cdot 20$ & $14 \cdot 33$ & $61 \cdot 43$ \\
\hline \multicolumn{6}{|c|}{ National Sugar Institute (NSI) } \\
\hline Actual & 1.235 & $11 \cdot 50$ & $35 \cdot 00$ & $45 \cdot 00$ & $60 \cdot 00$ \\
\hline Annular & $1 \cdot 230$ & $11 \cdot 55$ & $35 \cdot 15$ & $44 \cdot 81$ & 59.72 \\
\hline Fry & $1 \cdot 228$ & $11 \cdot 57$ & $35 \cdot 20$ & $44 \cdot 74$ & $59 \cdot 63$ \\
\hline Hawkes & $1 \cdot 124$ & $12 \cdot 64$ & $38 \cdot 46$ & $40 \cdot 95$ & $54 \cdot 58$ \\
\hline Asinari & $1 \cdot 210$ & $11 \cdot 77$ & $35 \cdot 82$ & 43.96 & 58.60 \\
\hline
\end{tabular}

The predicted gas yield for the annular digester at the parameters of operation of analogous reactors are the gas productivities achieved by the analogous reactors at their operational parameters within $\pm 10 \%$. The deviation in predicted gas yield, however, is within this same range whichever digester we simulate to predict its performance. Thus the figures for average gas productivity of plug flow digesters and their analogues are interchangeable. Further this result holds good whichever parameter we simulate. Thus, for example, the detention period for the annular layout for its initial run at $0.9 \%$ concentration of volatile solids, $33^{\circ} \mathrm{C}$ bioliquid temperature, $70 \%$ methane content and $0.035 \mathrm{~m}^{3} / \mathrm{day} / \mathrm{m}^{3}$ liquid in the digester gas produced has been predicted in table 6 as 99.85 days using Fry's data, 91.4 days with Hawkes data, 98.1 days using the parameters of the Asinari digester and $100 \cdot 4$ days with NSI data. The actual detention period has been 100 days. Thus the predictions for the detention period are within $\pm 10 \%$ for the annular design. That the performances of these analogous digesters are interchangeable is testified by the observation regarding independent predictions using measurements (table 5) reported by various authors around the world that the average of the ten deviations is 275 times less than the standard deviation of $5.784 \%$ - some $0.021 \%$. This also underscores the fidelity of measurements as well as of the simulation model for 
Table 7. Deviation of predictions in percentages

\begin{tabular}{llcrrrr}
\hline Digester & With respect to & Productivity & Concentration & Temperature & Detention & Methane \\
\hline Annular & Fry & 0.15 & -0.15 & -0.15 & 0.15 & 0.15 \\
& Hawkes & 8.61 & -9.42 & -9.42 & 8.61 & 8.61 \\
& Asinari & 1.87 & -1.91 & -1.91 & 1.87 & 1.87 \\
Fry & NSI & -0.43 & 0.43 & 0.43 & -0.43 & -0.43 \\
& Annular & -0.15 & 0.15 & 0.15 & -0.15 & -0.15 \\
& Hawkes & 8.47 & -9.25 & -9.25 & 8.47 & 8.47 \\
& Asinari & 1.73 & -1.76 & -1.76 & 1.73 & 1.73 \\
Hawkes & NSI & -0.58 & 0.58 & 0.58 & -0.58 & -0.58 \\
& Annular & -9.42 & 8.61 & 8.61 & -9.42 & -9.42 \\
& Fry & -9.25 & 8.47 & 8.47 & -9.25 & -9.25 \\
& Asinari & -7.37 & 6.86 & 6.86 & -7.37 & -7.37 \\
Asinari & NSI & -9.89 & 9.00 & 9.00 & -9.89 & -9.89 \\
& Annular & -1.91 & 1.87 & 1.87 & -1.91 & -1.91 \\
& Fry & -1.76 & 1.73 & 1.73 & -1.76 & -1.76 \\
& Hawkes & 6.86 & -7.37 & -7.37 & 6.86 & 6.86 \\
& NSI & -2.35 & 2.29 & 2.29 & -2.35 & -2.35 \\
\multirow{5}{*}{ NSI } & Annular & 0.43 & -0.43 & -0.43 & 0.43 & 0.43 \\
& Fry & 0.58 & -0.58 & -0.58 & 0.58 & 0.58 \\
& Hawkes & 9.00 & -9.89 & -9.89 & 9.00 & 9.00 \\
& Asinari & 2.29 & -2.35 & -2.35 & 2.29 & 2.29 \\
& Average & -0.156 & & & & \\
\hline
\end{tabular}

Standard deviation $=5 \cdot 735$.

digesters of the type considered. We should correlate this data also with the degree of volatile solids converted to gas.

This is given by the governing equation for the substrate utilisation for plug flow digesters and their analogues (Metcalf \& Eddy 1979):

$$
C=C_{0} \exp (K D),
$$

where $C$ is the volatile solid concentration at the end of the detention period $D$ days, and $C_{0}$ is the initial volatile solid concentration of substrate in the anaerobic digester system. $K$ is a negative number called the rate of reaction, days ${ }^{-1}$

Knowing the values for all parameters in the above equation for the various digesters cited in table 2 the reaction rate has been evaluated for each of the cited digesters and plotted in figure 3 . We see that the gas productivity, detention period and reaction rate are in agreement with one another as one should expect. Initially the reaction rate is low for low concentrations, and the gas productivity is also low, and thus the detention period is high to make up for the low reaction rate. At the level of concentration of the Asinari process, conditions are optimal with maximum gas productivity, maximum reaction rate, and consequently, minimum detention time. Beyond this, as depicted by the NSI, Kanpur, batch digester data as well as that of Fry's digester, the detention period again increases to make up for the lower reaction rates to achieve reasonable gas productivities at concentration levels much higher than $6 \%$, namely $11 \cdot 5 \%$ for the NSI and $20 \%$ for the Fry digester. Based on this result therefore we can expect our annular digester as shown in figure 3 to have very high gas productivities at appropriate parameters of operation characteristic of conventional plug flow digesters and their analogues cited here. The probability with which this would happen appears to be upwards of $99 \%$ considering the $0.021 \%$ average deviation in the predictions as compared to actual reported yields. 


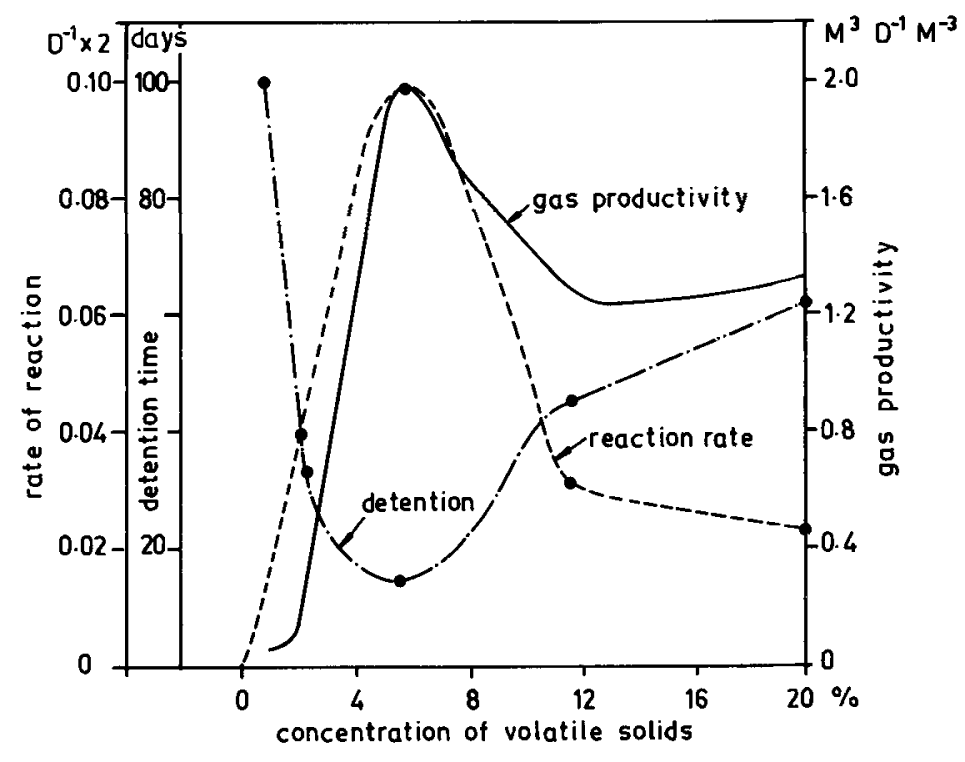

Figure 3. Predicted performance of the new digester.

On account of the very high degree of confidence for the expectation of high gas productivity at higher values of concentration of volatile solids, the potential for economical methane production, apart from reliability, seems high. On account of this, a preliminary analysis made for estimating the economics of intrinsic control design shows that the gas production at $35 \mathrm{~m}^{3}$ per day would be six times cheaper than in deep digesters for the same gas production capacity (Ashok Kumar, unpublished).

\section{Directions for further work}

The simulation done above of the annular layout suggests strongly that the predictions be confirmed in practice using volatile solid concentrations of the order of $6 \%$ overall in the concrete tank. It is at this concentration level that the Asinari two-stage digestion achieved maximum gas productivity of $2.0 \mathrm{~m}^{3} / \mathrm{day} / \mathrm{m}^{3}$ of digestion liquid volume and a minimum detention period of 14 days. Further, the concentration level could be slowly built up and the effects on digestion studied. This increase in loading could continue till a concentration level of $20 \%$ overall in the concrete tank is reached for the initial concentration. Measurements of $\mathrm{pH}$, alkalinity and volatile solid content may be made in the bioliquid, and of the methane content in the gas. The effect of removal and addition of material to the annular space in the process is to be studied.

\subsection{Digester response to addition of material}

Solid feed material addition to the annular space and its removal should not disturb digester performance when there is appropriate balance between material removed 
and material added. This is because the concentration gradient is changed only when volatile acids are made from the raw material by the hydrolysing bacteria. Thus, the gradient is changed continuously unlike in conventional layouts. Thus the annular space acts as a moderator between the dumped raw material and the anaerobic digester. As we change the concentration as suggested from lower to higher values (of the order of $20 \%$ ) we should expect a smooth transition permitting continuous operation even at different levels of loading, controlled intrinsically by the process itself. We will also have to assess by further work the behaviour when bioliquid removals and additions (like sewage and water) are effected. It is of interest to study here the degree of benign margin provided by the self-regulating action of the bioliquid encompassing the annular space as well as the anaerobic digester. Specially we would be interested in the amount of volatile solids utilised at various levels of concentration in this layout when the effluents are not removed, that is, when we operate in the mode of the initial run described in this paper. In this mode there is no chance for the 'garbage in-garbage out' phenomenon described in the introduction while referring to the conventional two-stage digestion process of Asinari et al (1980). Fry (1974) noted in this connection impending failure of his plug flow digestion with hog wastes after three months of operation with a daily loading rate of $40 \%$ volatile solids. It will be interesting to note when intrinsic control fails as we increase the loading rate.

\section{Conclusion}

A novel anaerobic digester layout has been described and intrinsic control of digestion demonstrated to be feasible. Its tremendous potential to permit digestion of a wide range of feed materials, without the problems faced by the conventional layout, has been highlighted. Reliable and economical digestion, characteristic of plug flow digesters, has been predicted while utilising two-phase digestion for various feed concentrations with gas productivity of the order of $1 \mathrm{~m}^{3} / \mathrm{day} / \mathrm{m}^{3}$ of liquid holding capacity of digester. This could be confirmed by actual use.

This work has been carried out in the Tata Electric Companies partly in the program on renewable resources. The author thanks the referee for his comments which has resulted in the paper in its present form.

\section{References}

Asinari di San Marrano C M. Naveau H P. Nyns E J 1980 in Energy from biomass. First European Community Conference (eds) W Palz, J Coombs, D O Hall (London: Elsevier Applied Science) pp. 392-397

DST 1981 A status report on biogas technology and utilization, Department of Science and Technology, Government of India, New Delhi, p. 65

Fry J L 1974 Practical building of methane power plants for rural energy independence (Andover, Hampshire: D A Knox) 
Hawkes F R, Floyd J R S, Hawkes D L 1980 in Energy from biomass. First European Community Conference (eds) W Palz, J Coombs, D O Hall (London: Elsevier Applied Science) pp. 398-405 Metcalf and Eddy Inc. 1979 Wastewater engineering: Treatment disposal and reuse 2 nd edn (ed.) G Tchobanoglous (New Delhi: Tata-McGraw Hill)

Subramanian D K, Rajabapaiah, Reddy A K N 1979 Proc. Indian Acad. Sci. C2: 365-375 